\title{
PACK-ICE MOTION IN THE WEDDELL SEA IN RELATION TO WEATHER SYSTEMS AND DETERMINATION OF A WEDDELL SEA SEA-ICE BUDGET
}

\author{
by
}

\author{
D.W.S. Limbert, S.J. Morrison, C.B. Sear,*
}

(British Antarctic Survey, Natural Environment Research Council, High Cross, Madingley Road, Cambridge CB3 OET, England, U.K.)

P. Wadhams, and M.A. Rowe

(Scott Polar Research Institute, University of Cambridge, Lensfield Road, Cambridge CB2 1ER, England, U.K.)

\begin{abstract}
As part of the Winter Weddell Sea Project 1986 (WWSP 86), a buoy, transmitting via TIROS-N satellites to Service Argos, was inserted into an ice floe in the southern Weddell Sea. Operational U.K. Meteorological Office numerical surface-pressure analyses, which utilized the buoy's measured values of air pressure and temperature, are used to assess the impact of weather systems on pack-ice movement. The motion of the buoy is shown to be related closely to the position of the circumpolar trough and to the tracks of depressions crossing the area. The tracks of this and other buoys deployed during WWSP 86 are analysed, together with the known drifts of some ice-bound vessels, to establish the overall movement of sea ice in the central and western Weddell Sea. Using these data, the area of ice transported northward out of the Weddell Sea is determined. Roughly $60 \%$ of the winter sea-ice cover is discharged out of the area, and is replaced by new ice formation in coastal polynyas and by influx of new ice from the east. In summer, a further $30 \%$ is discharged northward out of the region, leaving $40 \%$ cover and by implication a 30\% loss by melting.
\end{abstract}

\section{INTRODUCTION}

The Weddell Sea is a source of sea ice that flows northward into the path of the easterly Antarctic Circumpolar Current. The broad features of pack-ice movement and of the Weddell Sea circulation have been discussed by Carmack (1986) but details of both the pack-ice motion in winter and of the effects of large-scale weather systems crossing the Weddell Sea are missing.

In this study we are concerned with that area of the Weddell Sea bounded by the great circles joining the tip of the Antarctic Peninsula $\left(63.3^{\circ} \mathrm{S}, 55.0^{\circ} \mathrm{W}\right)$ to a point $65^{\circ} \mathrm{S}$, $30^{\circ} \mathrm{W}$ and thence to Kapp Norvegia $\left(71^{\circ} \mathrm{S}, 12^{\circ} \mathrm{W}\right)$, with an area of $2 \times 10^{6} \mathrm{~km}^{2}$. The central Weddell Sea is usually devoid of direct meteorological observations and conventional synoptic analyses can be suspect. Numerical analyses do, however, incorporate satellite-sounder data which improve analysis quality, although errors do still occur. Further improvement can be made by inserting ice-strengthened buoys into the pack ice to transmit meteorological data via polar-orbiting satellites. WWSP 86 provided an opportunity to use co-ordinated buoy deployment to improve the

*Present address: SAIC Polar Oceans Associates, 16 Miller's Yard, 10/11 Mill Lane, Cambridge CB2 1RQ, England, U.K. meteorological analyses and to determine the influence of atmospheric and oceanic forcing on sea-ice motion. These are also discussed in companion papers (Rowe and others, 1989; Wadhams and others, 1989). In this paper, we concentrate on gross ice motion over periods of days to months.

Buoy 0534 (WMO number 71513) was deployed on 29 December 1985 at $76^{\circ} \mathrm{S}, 33^{\circ} \mathrm{W}$, and sensor data and position fixes were processed by System Argos from 2 January 1986. From mid-March 1986, the data were circulated via the WMO Global Telecommunication System (GTS) to the meteorological analysis centres at the U.K. Meteorological Office and the European Centre for Medium Range Weather Forecasting. The buoy ceased transmitting on 24 April 1987 at $62^{\circ} \mathrm{S}, 43^{\circ} \mathrm{W}$.

\section{LONG-TERM DRIFT PATTERN}

The drift of buoy 0534 is shown in Figure 1. Initially, buoy 0534 paralleled the line of the coast and the ice shelf between $76^{\circ} \mathrm{S}, 33^{\circ} \mathrm{W}$ and $77^{\circ} \mathrm{S}, 46^{\circ} \mathrm{W}$ before turning and travelling north to reach $74^{\circ} \mathrm{S}$ by June ( $\mathrm{E}$ and $\mathrm{F}$ on Figure 1). It took a further 2 months to reach $71^{\circ} \mathrm{S}(\mathrm{G})$ and from there reached $69^{\circ} \mathrm{S}(\mathrm{H})$ in October. The buoy remained at this latitude until November before moving north again to reach $68^{\circ} \mathrm{S}$ in December. It stayed close to $66^{\circ} \mathrm{S}$ from January to March 1988 (J) before moving off rapidly north-east. The letters $A$ to $J$ in Figure 1 identify short-term, apparently anomalous deviations from the overall drift pattern. These fluctuations can be associated with specific weather sequences. Although the net distance covered during the identified oscillations and loops was of ten small, the actual distance travelled on a day-to-day basis was of ten quite large (Table I). The ratio of total distance travelled to the displacement of the buoy is called the "meander coefficient" (see Table I) after Dunbar and Whitman (1962). We note that the meander coefficient must be defined with respect to the overall time between the beginning and end of the observations, and the time step $(t)$ between successive measurements of position. In this paper $t=1 \mathrm{~d}$ but a shorter time step which revealed finer details of the buoy's motion would clearly give a larger meander coefficient for the same overall time.

\section{BUOY MOTION AND WEATHER SYSTEMS}

Eight periods have been selected to illustrate the influence of large-scale weather systems on the pack-ice motion evidenced by buoy 0534 . The first three A, B, and $C$ all show that well-defined looping occurred during the summer when there was more or less open pack $(5 / 10$ to $7 / 10$ ice cover). Thereafter, satellite imagery indicated greater concentrations $(9 / 10$ to $10 / 10)$. Surface-pressure and 


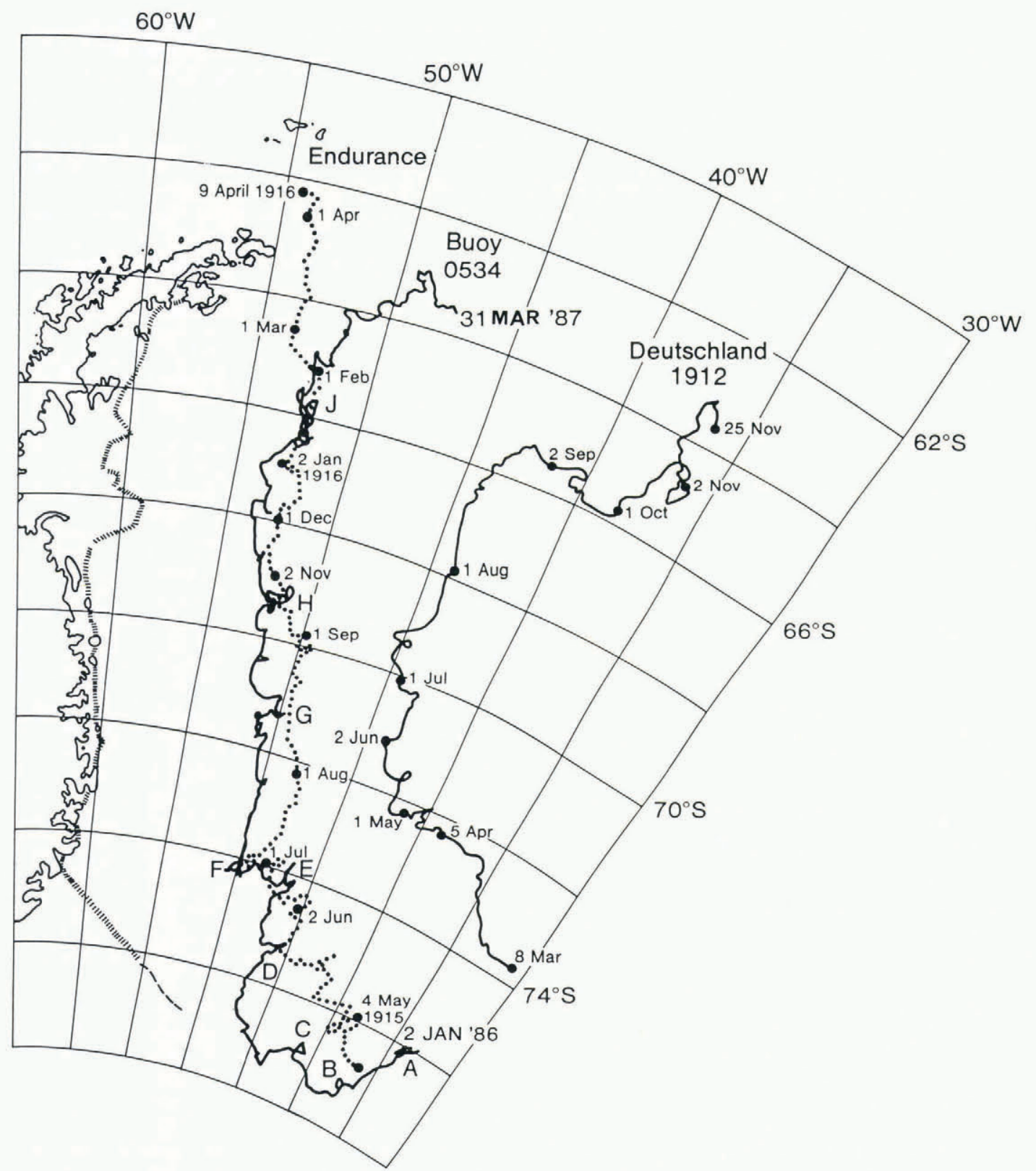

Fig. 1. Tracks of buoy 0534 (from 2 January 1986 to 31 March 1987), of Endurance (1915-16), and Deutschland (1912) (after Ackley, 1979). The letters indicate periods of buoy movement discussed in the text and in Table I.

temperature data measured by the buoy became available to the analysis centres during period $\mathrm{C}$ and a brief description of the synoptic meteorology for that and five subsequent periods follows.

\section{28 February-13 March 1986 (Fig. 2a and b)}

Ice motion in a closed cyclonic loop. A dominant ridge of high pressure extended to the south-west of the Weddell Sea and over the Antarctic Peninsula from $40^{\circ} \mathrm{S}$ giving moderate winds from the south-west. Between 7 and 9 March, the ridge declined and was replaced by a depression centred at $70^{\circ} \mathrm{S}, 55^{\circ} \mathrm{W}$. This moved to $65^{\circ} \mathrm{S}, 50^{\circ} \mathrm{W}$ by 11 March, producing easterly winds over the buoy. Between 11 and 13 March, the buoy resumed its generally south-westerly course.

\section{1-16 May 1986}

Ice motion to the north-east and then to the west. High pressure dominated the central Weddell Sea. The centre of the anti-cyclone moved slowly from $72^{\circ} \mathrm{S}, 45^{\circ} \mathrm{W}$ on 7 May to $72^{\circ} \mathrm{S}, 25^{\circ} \mathrm{W}$ on 13 May. Initially, winds over the buoy were from the south-west, backing to the northerly quarter by 13 May.
E and F. 30 May-2 July 1986 (Fig. 2c and d)

Movement north-east then south then west. The sea ice responded to a shift in the circumpolar trough from $75^{\circ} \mathrm{S}$ to $60^{\circ} \mathrm{S}$. Low pressure dominated the eastern side of the Weddell Sea between $78^{\circ} \mathrm{S}, 40^{\circ} \mathrm{W}$ and $73^{\circ} \mathrm{S}, 30^{\circ} \mathrm{W}$ until 10 June, giving southerly then westerly winds over the buoy. By 15 June, high pressure had replaced the low pressure and continued to dominate south of $70^{\circ} \mathrm{S}$, forcing a south or westward motion on the sea ice in the vicinity of the buoy. From 15 June, a belt of low pressure became established close to $60^{\circ} \mathrm{S}$ and this remained until the end of the period.

\section{G. 27 August-12 September 1986}

The buoy moved east then west. This change resulted from a shift in the tracks of the depressions across the area from $70^{\circ}$ to $65^{\circ} \mathrm{S}$.

\section{H. 29 October -9 November 1986}

The buoy moved in an irregular loop. The circumpolar trough was located at $74^{\circ} \mathrm{S}$, imparting eastward movement to the sea ice. This motion was reversed as the low-pressure zone moved north to $65^{\circ} \mathrm{S}$. 
TABLE I. MOTION OF BUOY 0534 IN THE SOUTHERN AND WESTERN WEDDELL SEA IN 1986 DURING INTERESTING PERIODS DEMARCATED IN FIGURE 1. A SUMMARY OF THE 12.00 GMT METEOROLOGICAL DATA COLLECTED BY THE BUOY IS INCLUDED

Pack-ice movement

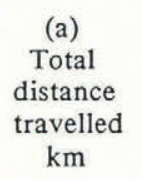

A $\quad 7-27$ Jan $\quad 76^{\circ} \mathrm{S} \quad 34^{\circ} \mathrm{W}$

B $\quad 8-17 \mathrm{Feb} \quad 77^{\circ} \mathrm{S} \quad 37^{\circ} \mathrm{W}$

C $\quad 28 \mathrm{Feb}-\quad 77^{\circ} \mathrm{S} \quad 41^{\circ} \mathrm{W}$

$13 \mathrm{Mar}$

D $\quad 1-16$ May $75^{\circ} \mathrm{S} \quad 46^{\circ} \mathrm{W}$

E-F 30 May- $74^{\circ} \mathrm{S} \quad 47^{\circ} \mathrm{W}$

$2 \mathrm{Jul}$

G 27 Aug $-71^{\circ} \mathrm{S} \quad 50^{\circ} \mathrm{W}$

12 Sep

H 29 Oct $-69^{\circ} \mathrm{S} \quad 52^{\circ} \mathrm{W}$

9 Nov

J $\quad 27 \mathrm{Dec}-\quad 66^{\circ} \mathrm{S} \quad 53^{\circ} \mathrm{W}$

$15 \mathrm{Feb}$

$\begin{array}{ccc}\text { (b) } & (\mathrm{c}) & (\mathrm{d}) \\ \text { Mean } & \text { Distance } \\ \text { speed } & \begin{array}{c}\text { Meander } \\ \text { coefficient }\end{array} \\ \mathrm{km} \mathrm{d}^{-1} & \begin{array}{c}\text { good } \\ \mathrm{km}\end{array} & \end{array}$

1.8

$9.8 \pm 11.5 \quad 108$

99

$11.0 \pm 5.7 \quad 89$

1.1

138

91

$6.1 \pm 2.0$

17

5.4

282

203

157

474

$9.5 \pm 4.9 \quad 104$

$14.3 \pm 5.0 \quad 34$

4.6

4.6
Meteorological means and extremes

$\begin{array}{ccc}\text { Pressure } & \text { Air temp. } & \text { Hull temp. } \\ \text { hp } & { }^{\circ} \text { C } & \text { Mean } \\ \text { Mean } & \text { Mean } & \text { Mean } \\ \text { Max. } & \text { Max. } & \text { Max. } \\ \text { Min. } & \text { Min. } & \text { Min. }\end{array}$

$1005.8 \quad-0.5$

$-8.7$

$\begin{array}{rr}998.2 & -8.7 \\ 1002.9 & -2.9\end{array}$

$992.8-11.3$

$992.9 \quad-9.8$

$\begin{array}{rr}992.9 & -2.9 \\ 1010.0 & -2.9 \\ 976.0 & -20.3\end{array}$

$1002.8 \quad-22.5$

$1015.0 \quad-13.4$

$980.0-34.7$

$997.9-26.6$

$1012.9-11.0$

$\begin{array}{ll}917.8 & -37.7\end{array}$

$979.6-21.1$

$1007.0 \quad-6.5$

$953.3 \quad-28.7$

973.6

1002.7

$-7.5$

$+1.9$

$954.9-14.6$

991.3

$-0.7$

$+3.4$

968.9
$-19.9$

$-22.8$

$-1.8$

$-2.0$

$-7.7$

$-18.4$

$-5.4$

$-0.1$

TABLE II. MEAN SPEEED, IN $\mathrm{m} \mathrm{s}^{-1}$, OF BUOY 0534 DURING THE FIRST 4 MONTHS OF 1986, CATEGORIZED ACCORDING TO THE STRENGTH OF THE FLOW (GYRE) AND LOCAL WIND SPEED

\begin{tabular}{lrr} 
Period & \multicolumn{2}{c}{ With G } \\
& \multicolumn{2}{c}{ With W } \\
$\begin{array}{l}\text { Day No. } \\
(N \text { cases })\end{array}$ & \multicolumn{2}{c}{$\mathrm{m} \mathrm{s}^{-1}$} \\
& \multicolumn{2}{c}{7.1} \\
$1-30$ & 0.17 & 7.1 \\
& $\pm 0.15 \quad$ & \pm 3.0 \\
$(28)$ & \multicolumn{2}{c}{$(14)$}
\end{tabular}

$31-60$

(29)

$61-90$

(30)

91-120

(28)

$$
\begin{array}{rr}
0.10 & 7.2 \\
\pm 0.07 & \pm 5.5
\end{array}
$$

(15)

$$
\begin{array}{rr}
0.12 & 8.2 \\
\pm 0.06 & \pm 3.8
\end{array}
$$

(16)

$$
\begin{array}{cc}
0.09 \quad & 7.8 \\
\pm 0.04 & \pm 4.5 \\
(20) &
\end{array}
$$
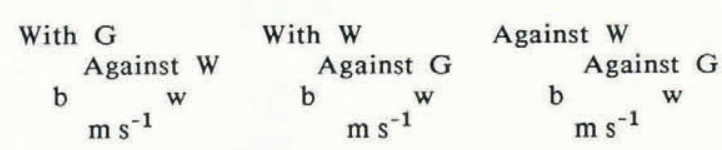

With $G$

$\mathrm{ms}^{-1}$

Variable W

b $\mathrm{m} \mathrm{s}^{-1}{ }^{\mathrm{w}}$

$\begin{array}{rr}0.06 & 2.4 \\ \pm 0.02 & \pm 2.1\end{array}$

(5)

$\begin{array}{cr}0.7 & 7.5 \\ \pm 0.05 & \pm 1.3\end{array}$

(2)

0.10

$0.07 \quad 5.8$

(4)

(3)

$\begin{array}{rr}0.06 & 5.7 \\ \pm 0.04 & \pm 1.5\end{array}$

(3)

$0.03 \quad 1.5$
$\pm<0.1 \quad \pm 1.0$

(5)

$0.07 \quad 1.5$
$\quad \pm 1.0$

(6)

$\begin{array}{rrrr}0.07 & 2.8 & 0.09 & 11.8 \\ <0.01 & \pm 0.3 & \pm 0.04 & \pm 2.6\end{array}$

(2)

(7)

0.01

(1)

$\begin{array}{rc}0.04 & 10.6 \\ \pm 0.01 & \pm 0.03\end{array}$

(2)

$\begin{array}{lrr}2.6 & 0.06 & 1.5 \\ & \pm<0.01 & \pm 1.0\end{array}$

(4)

$\begin{array}{lr}0.5 & 1.5 \\ \pm 0.03 & \pm 1.0\end{array}$

(6)

$\begin{array}{crr}1-120 & 0.11 & 7.6 \\ (115) & \pm 0.09 & (65)^{ \pm 4.3}\end{array}$

\begin{tabular}{crcr}
0.7 & 5.2 & 0.08 & 7.9 \\
\pm 0.04 & \pm 0.9 & \pm 0.03 & \pm 2.8 \\
$(4)$ & & \multicolumn{2}{c}{ (1) }
\end{tabular}
0.06
\pm 0.04

(8)

5.4
\pm 2.4

$0.05 \quad 1.5$

$\pm 0.02 \quad \pm 1.0$

(15)

b, buoy; w, wind speed $\left(0.1 \mathrm{~m} \mathrm{~s}^{-1}=8.64 \mathrm{~km} \mathrm{~d}^{-1}\right) ; \mathrm{G}$, gyre; W, wind. 
geostrophic wind was derived from the U.K. Meteorological Office numerical surface-pressure analyses for $00.00 \mathrm{GMT}$. The wind speed and direction so obtained are equivalent to the wind between 600 and $1000 \mathrm{~m}$ above the surface. The $10 \mathrm{~m}$ wind speed is approximately $20 \%$ less than this and is deflected by about $20^{\circ}$ to the right depending on surface roughness. Brennecke (1921) showed that on average the pack ice moved $34^{\circ}$ to the left of the surface wind. Thus, the pack-ice movement is within $15^{\circ}$ of the geostrophic wind and is indistinguishable from directions determined from the isobars of surface pressure. The daily mean displacement of the buoy was determined by successive daily positions closest to $12.00 \mathrm{GMT}$. Although not ideal, the $00.00 \mathrm{GMT}$ analyses do represent the average atmospheric pattern over the $24 \mathrm{~h}$ between successive location fixes, even for mobile weather systems. Only the first $120 \mathrm{~d}$ of charts have been analysed and until mid-March no buoy data were included in the numerical analyses. The results are summarized in Table II. The surface wind speeds are $80 \%$ of the estimated geostrophic wind.

The term "gyre" is used to indicate the overall longterm current system of the Weddell Sea. The pack-ice motion was assigned as moving predominantly in one of eight compass directions. Winds assisting this motion could be within $60^{\circ}$ of the direction of motion. Sea-ice velocity can only be accurately determined when the meander coefficient is close to 1 or when the sampling rate is less than $3 \mathrm{~h}$ (Thorndike, 1986). However, this study is restricted to net displacements of the sea ice on time-scales of days to months. A study of ice motion with a finer time-scale resolution is given in Rowe and others (1989).

Movement has been grouped into five categories for four $30 \mathrm{~d}$ periods:

1. With the gyre and with the local wind.

2 . With the gyre and against the local wind.

3. Against the gyre and with the local wind or with variable winds.

4. Against the gyre and against the local wind.

5. With the gyre and with light or variable winds.

Comparison of these five categories (Table II) shows that the motion in the direction of the main current assisted by the wind (category 1) is the dominant feature and is about $30 \%$ greater than when the wind and gyre are opposed (category 3). However, some of the wind speeds in category 3 are low, particularly in the first $30 \mathrm{~d}$ after deployment. Internal pack-ice resistance may have determined local-scale ice motion in some cases. Certainly, most of category 3 motion and categories 2 and 4 occurred during relaxation of the pack following prolonged periods of category 1 motion which compacted the pack ice. There may also be some categorization errors because, until mid-March, the synoptic analyses did not contain the buoy's data. These errors would be associated with slack pressure gradients and low wind speeds. Truly calm conditions or light variable winds allow the pack to respond to the gyre only and category 5 is thus a good estimate of the gyre/coastal current in the southern Weddell Sea, which here corresponds to a mean displacement of $4.3 \pm 1.7 \mathrm{~km} \mathrm{~d}^{-1}$

\section{ANNUAL PACK-ICE DRIFT}

The overall pack-ice movement is made clearer if the westward and northward components of the buoy's motion are presented separately (Fig. 3). The movement west after the first $100 \mathrm{~d}$ is in a series of discrete steps, as a consequence of the changing meteorological regimes described earlier. Considering the length scales of the atmospheric systems in the region (see, for example, Thorndike (1986)), a shift north of $5-10^{3}$ must affect a large proportion of the central Weddell Sea.

The mean northward drift of buoy 0534 is revealed by a straight-line fit by regression on Figure 3a between Day 1001986 and Day 59 1987. The regression equation is:

$$
\text { LATITUDE }=-80.42+(0.0372 \times \mathrm{DAY})
$$

where DAY is in the range 100-425. The standard error of the intercept is 0.0738 and that of the slope is $2.65 \times 10^{-4}$.
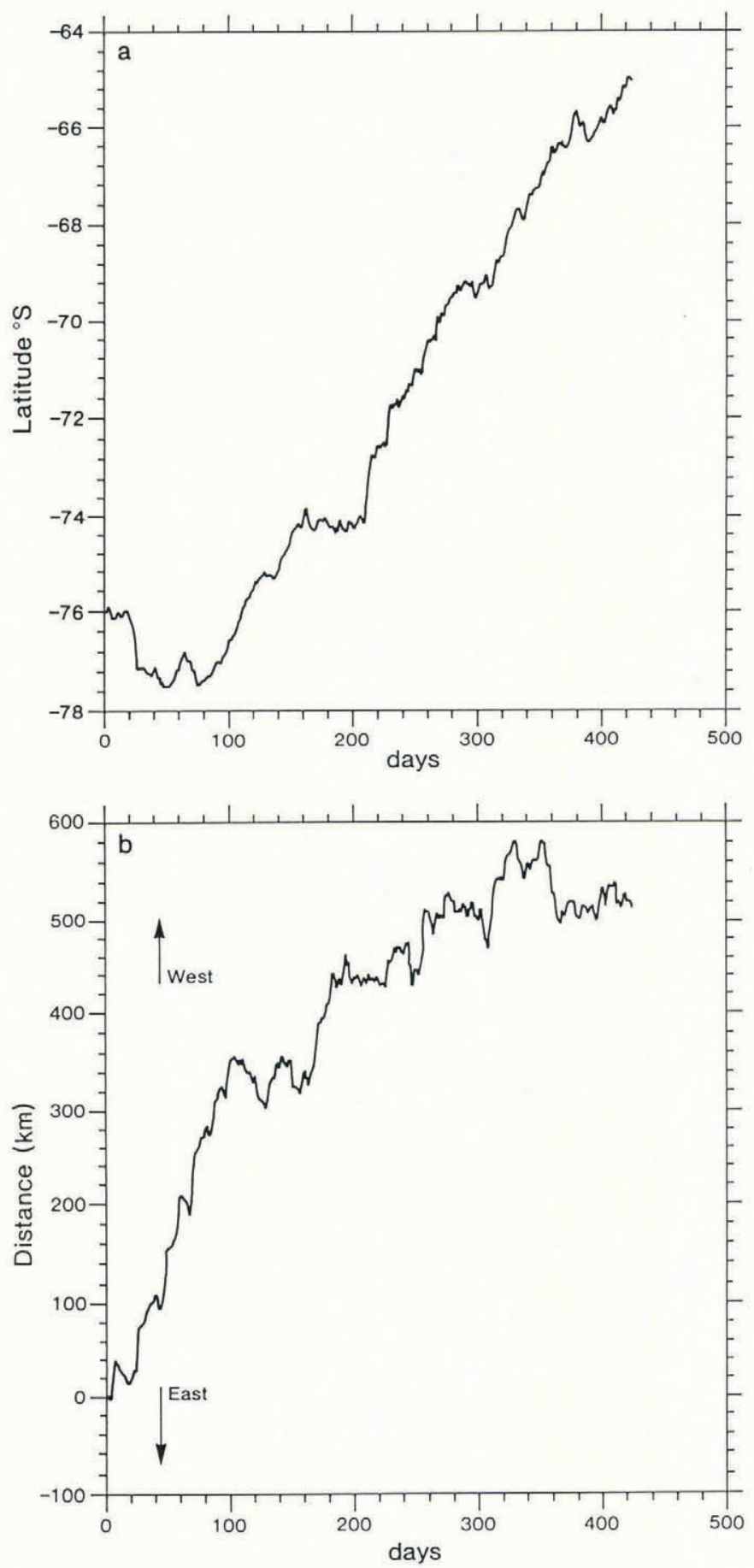

Fig. 3. Components of translation of buoy 0534 from 2 January 1986 to 28 February 1987. Northward translation is scaled by latitude and eastward translation is in kilometres.

This shows that the $95 \%$ confidence limits about the slope are small and the northward drift is close to that given by the regression-line slope. The standard error of the regression is 0.449 . The overall northward movement is $4.12 \pm 0.03 \mathrm{~km} \mathrm{~d}^{-1}$. That net speed is similar to the value determined for category 5 when the buoy was farther south, close to the ice shelf.

Northward motion, after near-stationary or westerly movement, ranged from 4.3 to $6.1 \mathrm{~km} \mathrm{~d}^{-1}$ over periods of 30-80 d. During Days 208-214, the pack moved north at the much higher rate of $14-35 \mathrm{~km} \mathrm{~d}^{-1}$ as compression was released after prolonged stable-blocking high pressure was replaced by a strong cyclonic circulation. Therefore, when comparing long-term drift from different years, periods in excess of $80 \mathrm{~d}$ are to be preferred. The calculation of the large-scale features of pack-ice motion over long periods may, because of significantly large meandering, conceal a 
TABLE III. NET DISPLACEMENTS, IN km d ${ }^{-1}$, FOR BUOYS DEPLOYED DURING WWSP 86

Buoy 0534, WMO 71513

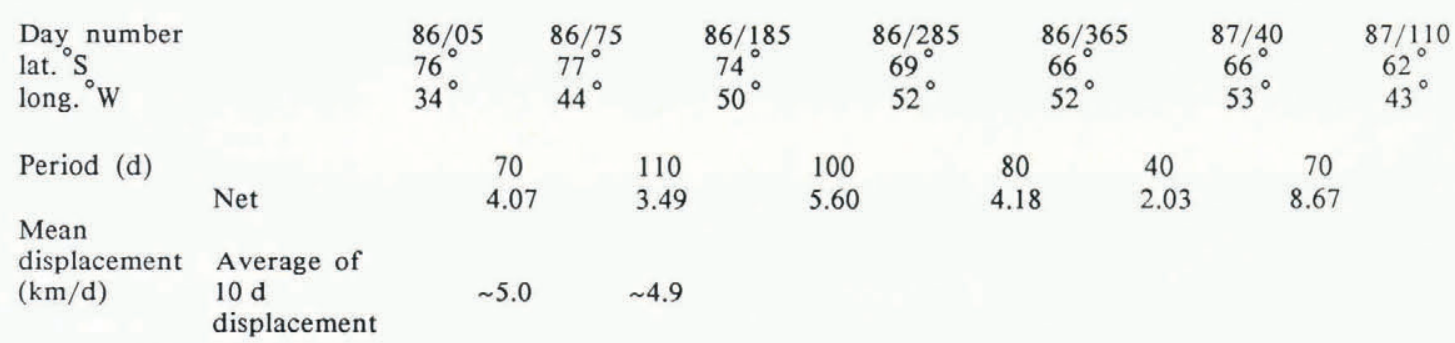

Buoys WMO 71514, 71515, and 71517

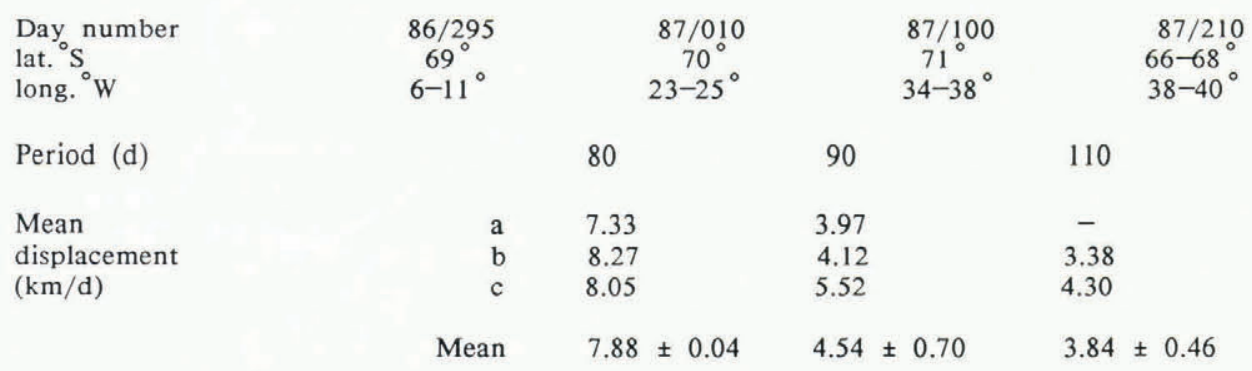

Buoys WMO 71516, 71518, and 71520

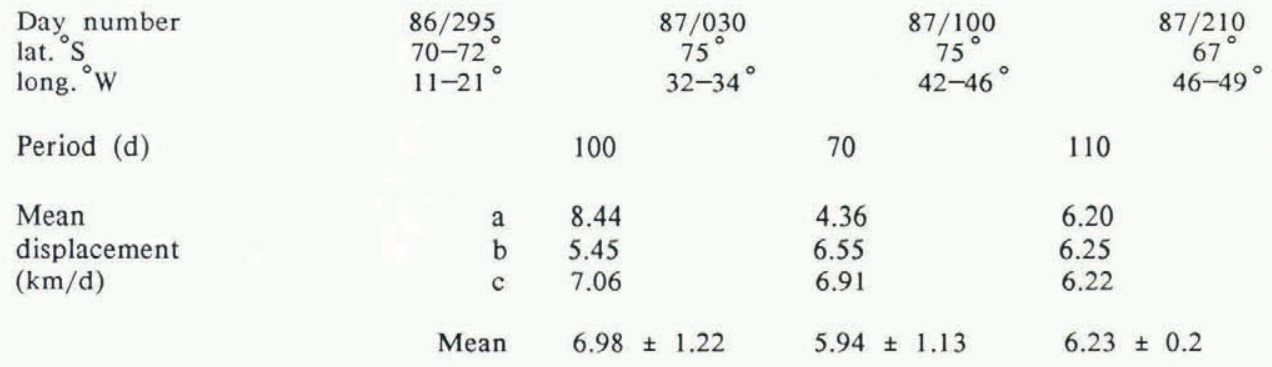

truer general speed of movement, just as a displacement over a few days conceals the daily meandering and hourly velocities (Thorndike, 1986). It is, however, this broad-scale motion which determines the net transport of sea ice around the Weddell Sea and its export into the Southern Ocean. For example, buoy 0534 in the two periods between day numbers $86 / 05$ and $86 / 185$ had total displacements averaging 4.07 and $3.49 \mathrm{~km} \mathrm{~d}^{-1}$, whereas an average of the $10 \mathrm{~d}$ displacements during the same periods gave speeds of 5.0 and $4.9 \mathrm{~km} \mathrm{~d}^{-1}$ (Table III). Which of these is the truer representation of the pack-ice gross speed? $5.0 \mathrm{~km} \mathrm{~d}^{-1}$ for the first period makes due allowance for the change in direction of the inshore current as it followed the ice front and was about half the value of the daily displacements $\mathrm{A}$, $B$, and $C$ shown in Table I. During the second period, the buoy followed a snake-like course which reduced the net displacement. However, the consistency of $4.9 \mathrm{~km} \mathrm{~d}^{-1}$ with the previous period suggests that this is a reasonable estimate of the mean wind-assisted movement.

The subsequent predominantly northward net displacement represented the best estimate of mean motion of the underlying ocean current. Averaged over the whole 220 d, from 4 July 1986 to 9 February 1987, the net speed of movement is $4.43 \mathrm{~km} \mathrm{~d}^{-1}$. As already demonstrated, the total distance travelled by an individual floe is much greater than its displacement during a specific period. The displacement of buoy 0534 between day numbers $86 / 75$ and $87 / 59$ was $1500 \mathrm{~km}$ but the total distance travelled was $3395 \mathrm{~km}$. This gives an overall meander coefficient of 2.26 , about half of that of the shorter, more active periods shown in Table I.
SPATIAL AND SECULAR VARIATION OF PACK-ICE MOTION

When the drift of buoy 0534 is compared with those of the ice-beset ships Endurance and Deutschland (Fig. 1), there is a remarkable similarity with the track of Endurance from July onwards. Further information is obtained from a number of transmitters dropped on to the pack ice in December 1978 and February 1980 in the south-western Weddell Sea (Ackley, 1981) and from a series of buoys deployed in the north-eastern Weddell Sea as part of WWSP 86 (Hoeber and Gube-Lenhardt, 1987; Schnack-Schiel, 1987).

The gross features of the WWSP 86 drifting buoys are shown in Figure 4 and a summary of their net displacements is given in Table III. The northward movement of these buoys, Ackley's buoys, and the two beset ships are tabulated in Table IV, which divides the area into $5^{\circ}$ longitude bands between $35^{\circ}$ and $60^{\circ} \mathrm{W}$.

The buoys deployed in the north-eastern Weddell Sea were grouped in threes which moved in concert. Each group exhibited three distinct phases. The northern group moved west for $80 \mathrm{~d}$ and then west-south-west with a large anti-clockwise loop which reduced the net displacement; the group then turned north. The southern group followed the coastal current south-west for $100 \mathrm{~d}$ then, after performing a smaller anti-clockwise loop in concert with the northern group, it moved west-north-west before it too turned north for the last $100 \mathrm{~d}$. This latter group closely followed the $2000 \mathrm{~m}$ bathymetric contour until reaching $45^{\circ} \mathrm{W}$. Both buoy 0534 and Endurance followed this contour after leaving the 


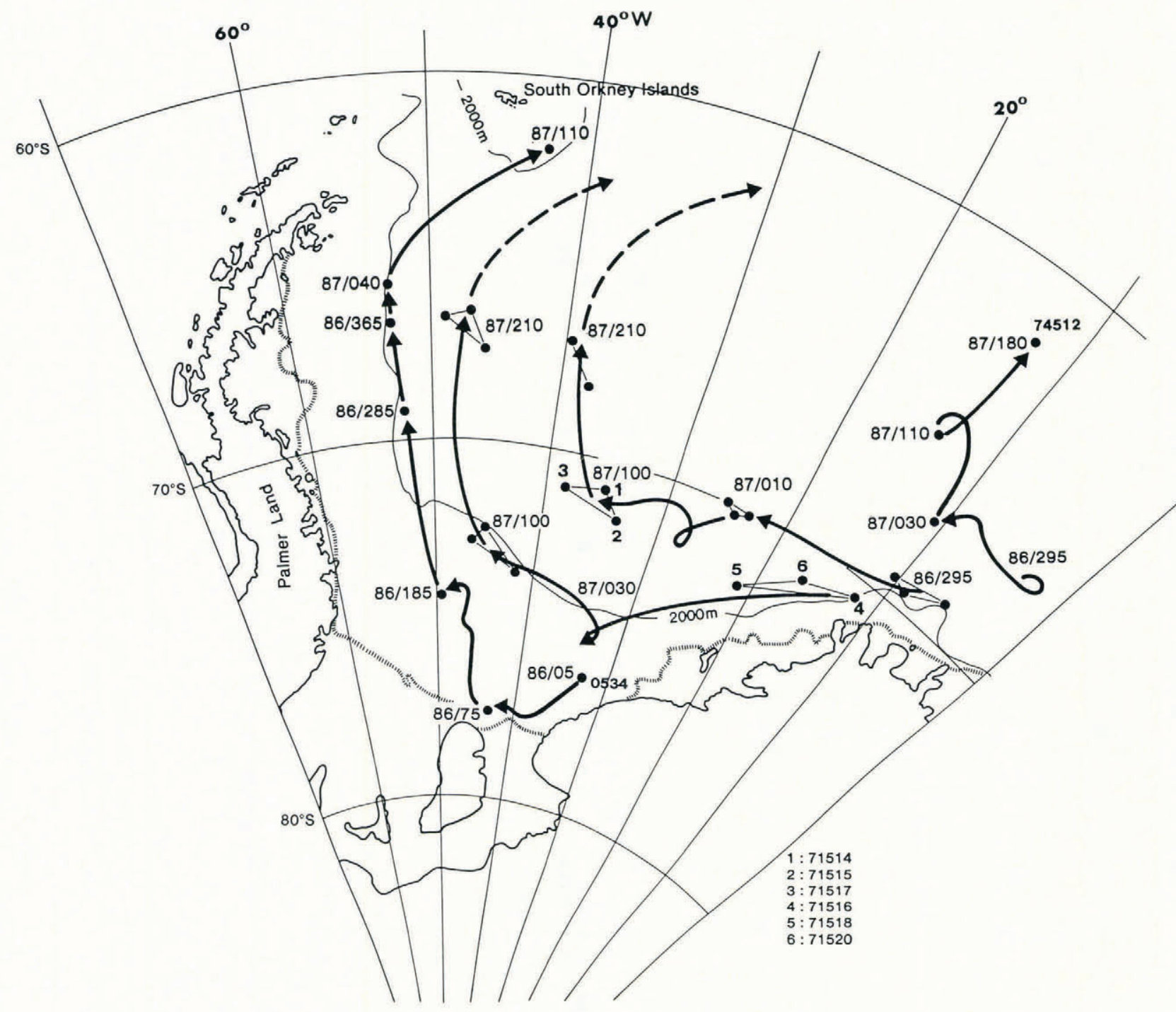

Fig. 4. Schematic showing the gross features of the tracks of the buoys listed in Table III, 1986-87.

TABLE IV. AVAILABLE DATA FOR THE NORTHWARD DRIFT OF PACK ICE IN THE WEDDELL SEA USING BUOY, AIR-DROPPED TRANSMITTER, AND BESET SHIP TRACKS. THE DATA ARE GROUPED INTO FOUR EQUAL LONGITUDINAL ZONES. THE TRACK OF ENDURANCE, WHICH MOVED BETWEEN TWO DIFFERENT ZONES, IS SUMMARIZED IN EACH ZONE IT OCCUPIED

Longitude band

$\underset{35-40^{\circ} \mathrm{H}}{\mathrm{A}}$ $\stackrel{\mathrm{B}}{40-45^{\circ} \mathrm{W}}$

$\underset{45-50^{\circ} \mathrm{W}}{\mathrm{C}}$

$\underset{50-55^{\circ} \mathrm{W}}{\mathrm{D}}$ $55^{\circ}-60^{\circ} \mathrm{W}$ $65^{\circ}$ and $75^{\circ} \mathrm{S}$

Year

Source data
(No. of buoys)

Start date

$1912 \quad 1987$

1987

(2)

$69^{\circ} \mathrm{S}, 50^{\circ} \mathrm{W}$

$$
77
$$

$\begin{aligned} & \text { Initial position } 66^{\circ} \mathrm{S}, 38^{\circ} \mathrm{W} 71^{\circ} \mathrm{S}, 38^{\circ} \mathrm{W} \\ & 72^{\circ} \mathrm{S}, 34^{\circ} \mathrm{W}\end{aligned}$

$\begin{array}{ll}72^{\circ} \mathrm{S}, 41^{\circ} \mathrm{W} \quad & 73^{\circ} \mathrm{S}, 40^{\circ} \mathrm{W} \\ & 71^{\circ} \mathrm{S}, 40^{\circ} \mathrm{W}\end{array}$

$74^{\circ} \mathrm{S}, 48^{\circ} \mathrm{W}$ $73^{\circ} \mathrm{S}, 48^{\circ} \mathrm{W}$

$74^{\circ} \mathrm{S}, 45^{\circ} \mathrm{W}, 72^{\circ} \mathrm{W}, 73^{\circ} \mathrm{W}$

Final position $63^{\circ} \mathrm{S}, 36^{\circ} \mathrm{W}$ $67^{\circ} \mathrm{S}, 40^{\circ} \mathrm{W}$

$66^{\circ} \mathrm{S}, 42^{\circ} \mathrm{W} \quad 60^{\circ} \mathrm{S}, 21^{\circ} \mathrm{W}$

\section{$70^{\circ} \mathrm{S}, 50^{\circ} \mathrm{W}$} $60^{\circ} \mathrm{S}, 27^{\circ} \mathrm{W}$ $73^{\circ}, 45^{\circ} \mathrm{W}$ $64^{\circ} \mathrm{S}, 40^{\circ} \mathrm{W}$ $61^{\circ} \mathrm{S}$,

\begin{abstract}
6.3
\end{abstract}

5.8
5.3

$\begin{array}{ll}3.3 & 4.9 \\ 3.1 & 6.5\end{array}$

3.2

5.7

6.1
110

$\begin{array}{cl}1986 & 1979 \\ \text { WWSP 86 } & \text { Ackley }\end{array}$

$\begin{array}{cc}\text { (1) } & \text { (2) } \\ & \end{array}$

(0534)

$4 \mathrm{Jul} 21 \mathrm{Dec}$

$220 \quad 103$

103
130

$70^{\circ} \mathrm{S}, 58^{\circ} \mathrm{W}$ $73^{\circ} \mathrm{S}, 58^{\circ} \mathrm{W}$ $\begin{array}{lll}68^{\circ} \mathrm{S}, 46^{\circ} \mathrm{W} & 65^{\circ} \mathrm{S}, 52^{\circ} \mathrm{W} \quad 65^{\circ} \mathrm{S}, 53^{\circ} \mathrm{W} \quad 69^{\circ} \mathrm{S}, 57^{\circ} \mathrm{W} \\ 66^{\circ} \mathrm{S}, 47^{\circ} \mathrm{W} & & 70^{\circ} \mathrm{S}, 56^{\circ} \mathrm{W}\end{array}$ $67^{\circ} \mathrm{S}, 49^{\circ} \mathrm{W}$ 
continental shelf at $72.5^{\circ} \mathrm{S}, 50^{\circ} \mathrm{W}$. Their motions would suggest a measure of steering by the under-water topography.

None of the buoys deployed north of $75^{\circ} \mathrm{S}$ penetrated south of that latitude. Buoy 0534 , placed south of $75^{\circ} \mathrm{S}$, followed the coastline until it turned north near Berkner Island. Apart from the greater resistance to westward progress caused by the quasi-permanent sea ice closer to the Antarctic Peninsula, there may be an outflow of water northward from beneath the Filchner Ice Shelf as part of a cyclonic circulation beneath the ice shelf (Carmack and Foster, 1975).

The track of one other buoy (74512) is also shown in Figure 4 to illustrate the divergence which takes place near $68^{\circ} \mathrm{S}, 12^{\circ} \mathrm{W}$. The timing of the southernmost point of this buoy on 30 January 1987 coincides with the southernmost positions of the other two groups of buoys. This south-west motion over $20 \mathrm{~d}$ extended over the whole pack-ice area between $67^{\circ} \mathrm{S}, 10^{\circ} \mathrm{W}$ and $75^{\circ} \mathrm{S}, 34^{\circ} \mathrm{W}$, and represents the effect on the summer pack of an area of low pressure centred over the Weddell Sea. The subsequent looping occurred as high pressure developed and the circumpolar trough moved north to $65^{\circ} \mathrm{S}$.

Comparing the northward motion of pack ice in the central and western Weddell Sea (Table III) and noting the discharge rates from the different longitude bands, we obtain the following relationships:

$$
\begin{aligned}
& \text { in } 1912 \mathrm{~A}>\mathrm{C} \text {, } \\
& \text { in } 1915 \mathrm{C}>\mathrm{D}, \\
& \text { in } 1979 \mathrm{C} \gg \mathrm{E}, \\
& \text { in } 1980 \mathrm{~B} \approx \mathrm{C}, \\
& \text { in } 1987 \mathrm{~A} \ll \mathrm{C} \text {. }
\end{aligned}
$$

From this we can deduce that the rates of discharge from the areas are in the following order:

$$
\mathrm{A}<\mathrm{B} \simeq \mathrm{C}>\mathrm{D}>\mathrm{E}
$$

so that the fastest discharge lies between $40^{\circ}$ and $50^{\circ} \mathrm{W}$. Assuming that in most years $\mathrm{B} \simeq \mathrm{C}$, we can deduce the following:

in band $\mathrm{A}, 1912>1987$;

in $\mathrm{B}$ and C combined, $1912>1987>1980>1979$.

The track of Endurance crossed from C to D but may still be compared to the track of buoy 0534 and shows that the discharge rate for $1915 \simeq$ discharge rate for 1986 . That discharge rate lies between those for 1979 and 1980; thus the ranking of discharge rates for each year is:

$$
1912>1987>1980>1915 \simeq 1986>1979 .
$$

From satellite imagery, we know that pack ice extended north of South Georgia $\left(54^{\circ} \mathrm{S}, 35^{\circ} \mathrm{W}\right)$ in both 1980 and 1987 - both years of high discharge rate - and was much farther south in 1979 and 1986 with slower discharge rates. It is tempting to relate the ice-discharge rates to mean annual temperature in the South Orkney Islands; Budd (1975) has shown that there is about a $2^{\circ}$ northward extension of pack ice associated with an annual temperature reduction of $1^{\circ} \mathrm{C}$ at that latitude. However, both 1912 and 1915 were cold years in the South Orkney Islands (Jones and Limbert, 1987), although the discharge rates were widely different.

It is to be expected that when low pressure is concentrated in the eastern Weddell Sea within $5^{\circ}$ latitude of $70^{\circ} \mathrm{S}$, and between $20^{\circ}$ and $35^{\circ} \mathrm{W}$, the ice-discharge rates are likely to be higher than average, with cold southerly winds predominating at the South Orkney Islands. Such situations occur from time to time when high pressure extends south from South America and blocking occurs near the northern half of the Antarctic Peninsula. Such blocking in the region is common (Trenberth and Mo, 1985). Conversely, frequent passage of depressions across the northern tip of the Antarctic Peninsula into the Scotia Sea between $60^{\circ}$ and $65^{\circ} \mathrm{S}$, concomitant with high pressure extending north into the Weddell Sea, will retard ice movement northward. Such situations developed from time to time in 1986, but in early 1987 blocking anti-cyclones close to the tip of the Antarctic Peninsula were more common. This suggests that 1987 began with relatively high discharge out of the Weddell Sea with cold southerly winds.

\section{WEDDELL SEA SEA-ICE BUDGET}

The term budget is used here to describe the changes of the pack-ice area. The loss of ice cover from an area is a visible sign that there is a mass loss by under-water melting throughout the whole pack. Correspondingly, the increase in area indicates pack-ice thickening. From the hull-temperature record of buoy 0534, we know that growth was occurring from March through to October and that under-water melting occurs in the northern Weddell Sea during the 4 months November-February. This was similar to results found by Limbert (1968) at Halley Bay $\left(75^{\circ} \mathrm{S}\right.$, $\left.26^{\circ} \mathrm{W}\right)$.

The equation of areal continuity for the Weddell Sea could be written as:

CHANGE IN ICE AREA = AREAL OUTFLOW - AREAL INFLOW LOCAL FORMATION.

In this paper we have presented data on outflow (discharge speed). The areal extent of sea ice is known from satellite imagery and ice influx from the east can be estimated and so, if the width of the front through which northward discharge occurs is known, an estimate of the summer melt can be made.

Additional WWSP 86 buoys were placed close to $67^{\circ} \mathrm{S}$, $0^{\circ} \mathrm{W}$ (Schnack-Schiel, 1987), and drifted northward and then turned east. Their divergence from those placed further west implies that there is little net inflow or outflow near $65^{\circ} \mathrm{S}$, $30 \mathrm{~W}$. In 1986 and early 1987, the mean northward discharge speed, ignoring the slow-moving boundary region $\mathrm{D}$, was $5.0 \mathrm{~km} \mathrm{~d}^{-1}$ between $35^{\circ}$ and $50^{\circ} \mathrm{W}$ at $65^{\circ} \mathrm{S}$. The areal discharge rate of sea ice northward is thus of the order of $5000 \mathrm{~km}^{2} \mathrm{~d}^{-1}$. This represents a total outflow of $1.8 \times 10^{6} \mathrm{~km}^{2} \mathrm{year}^{-1}$, which represents approximately $90 \%$ of the defined area of the Weddell Sea. If this were to be balanced by an influx of $8.0 \mathrm{~km} \mathrm{~d}^{-1}$ over the $625 \mathrm{~km}$ front extending from Kapp Norvegia to $67.5^{\circ} \mathrm{S}, 25^{\circ} \mathrm{W}$, then the equation of continuity would be satisfied. However, from limited information available which suggests divergence north of $70^{\circ} \mathrm{S}$ at $20^{\circ} \mathrm{W}$, the influx of ice is possibly less than the total required for balance.

Assuming an annual discharge of $90 \%$ of the defined area at a constant rate, the seasonal budgets are as follows:

Winter (March-October, 8 months)

(a) $60 \%$ of the Weddell Sea sea-ice is discharged into the Southern Ocean.

(b) This must be replaced by formation of new ice in polynyas and by influx from the east, south of $70^{\circ} \mathrm{S}$ and near Kapp Norvegia.

Summer (November-February, 4 months)

(a) $30 \%$ of the preceding winter sea ice is discharged.

(b) $40 \%$ of the area remains covered (Zwally and others, 1983); and so

(c) $30 \%$ of the sea ice melts in situ.

The analysis is consistent with the evidence from satellite passive microwave observations for the 1973-76 period as presented by Zwally and others (1983). They generated maps of monthly changes in sea-ice concentration which show the major areas of melt within the Weddell Sea.

\section{CONCLUSIONS}

The movements of satellite-tracked buoys and of vessels beset in ice have been analysed to study the sea-ice motion of the Weddell Sea. It is clear that the major vacillations of the sea-ice field in the region result from the movement of the atmospheric circumpolar trough, through its influence on the motions of individual weather systems. We have demonstrated the type of influence of these weather systems 
in the region. The spatial and temporal consistency of the northward motion in the central and western Weddell Sea indicates the strength of the underlying northward current which forms a part of the Weddell Sea circulation. There are notable year-to-year variations in the overall northward translation. In 1986, in the western sector, it was $4.2 \mathrm{~km} \mathrm{~d}^{-1}$ (Fig. 2) but the mean value for the various years is closer to $5.0 \mathrm{~km} \mathrm{~d}^{-1}$. Using all available ice-drifter data, it has been possible to determine a sea-ice budget for the Weddell Sea. It has been found that each winter approximately $60 \%$ of the Weddell Sea sea ice is moved northward into the Southern Ocean, and that this amount is replaced by influx from the east and by the formation of new ice in leads and coastal polynyas. In summer, about $30 \%$ of the previous winter's ice load is discharged to the north, a further $30 \%$ melts in situ, leaving the remaining $40 \%$ covered by ice. In the light of this areal budget, it would seem unlikely that any mobile pack ice in the Weddell Sea is more than 2 years old, and that the majority is first-year ice.

\section{FUTURE WORK}

Three main questions arise. How consistent is the Endurance $/ 0534$ track, what area of pack ice moves simultaneously under the influence of atmospheric forcing, and how real is the apparent quasi-stationary zone at $65^{\circ} \mathrm{S}$ between $10^{\circ}$ and $30^{\circ} \mathrm{W}$ ? To answer the first, a regular annual deployment of a buoy at $76^{\circ} \mathrm{S}$ between $30^{\circ}$ and $35^{\circ} \mathrm{W}$ is in progress. To answer the second requires an array of buoys between $70^{\circ}$ and $76^{\circ} \mathrm{S}$, and between $30^{\circ}$ and $35^{\circ} \mathrm{W}$. The third question could best be answered by a line of buoys from $65^{\circ}$ to $70^{\circ} \mathrm{S}$ between $15^{\circ}$ and $25^{\circ} \mathrm{W}$. It would be difficult to implement the latter two deployments without the aid of aircraft.

\section{ACKNOWLEDGEMENTS}

We are very grateful for the material help and collaboration given throughout WWSP 86 by V. Squire, then at Scott Polar Research Institute, Cambridge, and to E. Augstein of the Alfred-Wegener-Institut für Polar- und Meeresforschung, Bremerhaven. Especially, thanks are due to the latter scientist and to $H$. Hoeber of Meteorologisches Institut der Universität Hamburg, and to C. Kottmeir of the Institut für Meteorologie und Klimatologie der Universität Hannover, for allowing us to use the position data for the buoys deployed from FS Polarstern during WWSP 86. The U.K. Meteorological Office numerical analyses provided a vital source of information. The analysis charts are published by permission of the Director General of the U.K. Meteorological Office.

\section{REFERENCES}

Ackley, S.F. 1979. Mass-balance aspects of Weddell Sea pack ice. J. Glaciol., 24(90), 391-405.

Ackley, S.F. 1981. Sea-ice atmosphere interactions in the Weddell Sea using drifting buoys. Association of Hydrological Sciences Publication 131 (Symposium at Canberra 1979 - Sea Level, Ice and Climatic Change), 177-191.

Brennecke, W. 1921. Die ozeanographischen Arbeiten der Deutschen Antarktischen Expedition 1911-12. Aus Arch. Dtsch. Seewarte, 39(1).

Budd, W.F. 1975. Antarctic sea-ice variations from satellite sensing in relation to climate. J. Glaciol., 15(73), 417-427.

Carmack, E.C. 1986. Circulation and mixing in ice-covered waters. In Untersteiner, N., ed. The geophysics of sea ice. New York, Plenum Press, 641-712. (NATO ASI Ser., Ser. B, Physics, 146.)

Carmack, E.C. and T.D. Foster. 1975. Circulation and distribution of oceanographic properties near the Filchner Ice Shelf. Deep-Sea Res., 22(2), 77-90.

Dunbar, M. and W. Wittman. 1963. Some features of ice movement in the Arctic Basin. In Proceedings of the Arctic Basin Symposium, October 1962. Washington, DC, Arctic Institute of North America, 90-108.

Hoeber, H. and M. Gube-Lenhardt. In press. The Drifting Buoy Data Set. Part 1: the eastern Weddell Sea network. Ber. Polarforsch.

Jones, P.D. and D.W.S. Limbert. 1987. A data bank of Antarctic surface temperature and pressure. Washington, DC, U.S. Department of Energy. Office of Energy Research. (DOE/ER/60397-H2.)

Limbert, D.W.S. 1970. The thermal balance of sea ice at Halley Bay. International Assoication of Scientific Hydrology Publication 86 (ISAGE), 520-541.

Rowe, M.A., C.B. Sear, S.J. Morrison, P. Wadhams, D.W.S. Limbert, and D.R. Crane. 1989. Periodic motions in Weddell Sea pack ice. Ann. Glaciol., 12, 145-151.

Schnack-Schiel, S.B., ed. 1987. The winter expedition of RV "Polarstern" to the Antarctic. Ber. Polarforsch., 39.

Thorndike, A.S. 1986. Kinematics of sea ice. In Untersteiner, N., ed. The geophysics of sea ice. New York, Plenum Press, 489-549. (NATO ASI Ser., Ser. B, Physics, 146.)

Trenberth, K.E. and K.C. Mo. 1985. Blocking in the Southern Hemisphere. Mon. Weather Rev., 113, 3-21.

U.S. Navy. 1985. Sea ice climatic atlas. Volume I. Antarctic. Asheville, NC, Naval Oceanography Command Detachment.

Wadhams, P., C.B. Sear, D.R. Crane, M.A. Rowe, S.J. Morrison, and D.W.S. Limbert. 1989. Basin-scale ice motion and deformation in the Weddell Sea during winter. Ann. Glaciol., 12, 178-186.

Zwally, H.J., J.C. Comiso, C.L. Parkinson, W.J. Campbell, F.D. Carsey, and P. Gloersen. 1983. Antarctic sea ice, 1973-1976: satellite passive-microwave observations. Washington, DC, National Aeronautics and Space Administration. (NASA SP-459.) 